DOI https://doi.org/10.30525/978-9934-26-114-5-11

\title{
МЕТОДИ ДІАГНОСТИКИ ДИТЯЧО-БАТЬКІВСЬКИХ СТОСУНКІВ ТА ПСИХОЛОГІЧНОГО МІКРОКЛІМАТУ РОДИНИ, ЩО ВИХОВУЮТЬ ДИТИНУ 3 ООП
}

\author{
Реброва О. О. \\ аспірант \\ Інститут спеціальної педагогіки і психології імені Миколи Ярмаченка \\ Національної академії педагогічних наук Украӥни \\ м. Київ, Україна
}

Метою діагностичної роботи 3 батьками $є$ визначення типу сімейного виховання, установок батьків по відношенню до дітей i власної родини. В першу чергу родина є психологічною середою, в якій розвивається дитина, тому важлива іiі ефективність і стимуляція іiі розвитку. Для реалізації цього завдання необхідно вивчати та проводити якісну діагностику психологічного клімату в родині, батьківські стилі виховання та виховну компетентність батьків, ціннісні орієнтації, рівень домагань, а так само самооцінку [3].

Загальний фокус при діагностиці дитячо-батьківських стосунків в родині, що виховує дитину з ООП повинен утримуватися на дитині, це означає виявлення у життєдіяльності окремої родини порушень, які сприяють виникненню або збереженню у дитині труднощів у повсякденному житії та нервово-психічних розладів або якість та кількість реабілітаційних заходів дитини. Також фокусом має стати визначення тих психологічних особливостей родини і ії членів, від яких залежить корекція порушень і які, відповідно, потрібно враховувати при виборі методу надання психологічної допомоги (сімейного консультування або психотерапії та ін.) та ії реалізації.

Не мало суттєвим під час вибору методів діагностики дитячобатьківських стосунків та психологічного мікроклімату родини, що виховують дитину з ООП, стає діагностика психічного розвитку дитини яка містить в собі два положення: причини порушення поведінки i розвитку дитини можуть знаходитися або в особливостях ставлення батьків до дитини та їхньому стилі виховання, або у викривленнях внутрішньої логіки саморозвитку дитини, або у порушенні процесу спілкування між дітьми і батьками, або у комбінації даних чинників. Друге положення витікає з першого і полягає у побудові структури діагностики за принципом дерева: кожен наступний діагностичний 
крок робиться тільки у тому випадку, якщо отримано відповідний результат на попередньому. Також діагностика психічного розвитку дитини при діагностиці дитячо-батьківських стосунків та психологічного мікроклімату родини, стає важливою бо висновки, які отримані при діагностиці психічного розвитку дитини допоможуть підібрати методи які дозволять уникнути вторинного травмування родини.

Серед методів вивчення сім’ї останнім часом досить стали: психологічні опитування, інтерв'ювання та анкетування.

У психотерапевтичної практиці використовуються кілька видів інтерв'ю.

Інтерв'ю по Генограмі, під час якого психолог рухається від представленої проблеми до більш широкого сімейного і соціального контексту; від справжньої сімейної ситуації до історичної хронології сімейних подій. [5] Використовуючи дані генограми, психолог може допомогти членам родини подолати негативне сприйняття один одного. Подібне інтерв'ю може поліпшити відносини членів родини з лікарем та поліпшити медичне лікування. Опитування по Генограмі сфокусоване не тільки на проблемах і труднощах родини, а також виявляє успіхи iï членів і способи ефективної адаптації.

В інтерв'ю - простеження послідовностей взаємодії «простеження» означає надання пояснюють питань, надавання схвальних коментарів або витяг подробиць. Операція простеження $є$ типовою для психолога, що не нав'язує своєї думки. Інтерв'ю триває до тих пір, поки не позначиться повна послідовність подій. Питання представлені в безоціночною манері, психолог просто цікавиться, що родина робить. Крім діагностичного значення ця техніка $\epsilon$ найважливішим елементом в процесі приєднання до родини і м'якого керівництва нею в напрямку нової поведінки.

Циркулярний інтерв'ю також використовує технологію простеження, комунікацій з акцентом на виявлення відмінностей між членами сім'ї. Проводячи інтерв'ю з родинами, виявляється корисним складати спрощену генограму трьох поколінь родини. «Підтримка» містить в собі елементи двох попередніх інтерв'ю і виражається в уважному вислуховуванні, емпатичних репліках, додаткових питаннях i позитивному новому визначенні ролі члена родини і родини в цілому. Педагог активно збирає інформацію про проблеми, використовуючи спостереження. Він повинен відзначити той настрій, 3 яким члени родини приходять. Він зазначає взаємини між батьками. Коли дитина $€$ проблемою, часто у батьків існує незгода в тому, як його виховувати. Природа запитань дозволяє членам родини «відкрити» нову реальність в своїх відносинах, що запускає зміни в системі родини. 
Оціночна інтерв'ю повинно давати можливість психологу отримувати інформацію про сімейні структури, взаємодіях, історичне коріння родини і завданнях життєвого циклу, 3 якими родина не справляється в даний момент.

Наступним методом може стати -метод анкетування тобто письмове опитування. Цей метод відрізняється достатньою валідністю. Психолог може використовувати різні види анкетування: контактне, коли сам дослідник

організовує анкетування і збирає опитувальні листи, заочне - коли анкети 3 інструкціями розсилаються. Залежно від завдань, які треба дослідити, а також особливостей родин можливі різні типи анкет: відкрита - містить питання, на які належить відповісти випробуваному; закрита - до питань даються можливі варіанти відповідей; змішана пропонуються можливі відповіді і одночасно можна сформулювати деякі відповіді по-своєму.

У літературі $\epsilon$ достатня кількість методів діагностики дитячобатьківських стосунків та психологічного мікроклімату родини. Серед яких Тест-опитувальник батьківського ставлення (А. Я. Варга) дає можливість проаналізувати ставлення батьків до дитини, визначити базовий тип виховання і характер сприйняття матір'ю своєї ролі в житті дитини не тільки якісно, але і кількісно, завдяки наявності системи шкал. Але не менш інформативною ніж анкета, може бути-жива розмова, особливо попередньо структурована. При заповненні якої можливі різні спотворення. 3 іншого боку, метод інтерв'ю вимагає створення умов, які мають до щирості респондентів. В загалі при вивченні родини психолог найчастіше використовує методи бесіди та спостереження.

Вважається, що бесіда відрізняється від інтерв'ю більшою свободою і в організації, і в змісті, неформальною атмосферою і відносинами між співрозмовниками, хоча ці відмінності не абсолютні. Бесіда може служити для підтвердження, конкретизації або спростування якихось гіпотез, які виникли на основі вивчення родинних взаємин за допомогою інших методів. I тут на допомогу може прийти використання методу емпатичного слухання (К. Роджерс, Т. Гордон). Емпатія - це почуття розуміння і співпереживання психологічного стану іншої людини. Суть методу - створення атмосфери зацікавленого розмови, спільного вирішення проблеми.

Також хочеться звернути увагу, що існують методи, за допомогою яких одночасно i вивчається, i коригується позиція батьків. В результаті такого підходу батьки розглядають запропоновані методи 
як власні напрацювання і більш охоче впроваджують їх у свою психологічну практику.

Останнім часом нерідко застосовуються методи психокорекції, такі як психологічний тренінг, в якому беруть участь члени кількох сімей, які мають подібні проблеми. Їм пропонуються завдання, виконання i спільне обговорення яких повинно допомогти виробленню умінь i навичок, необхідних ціннісних змін для спільного життя 3 дитиною 3 особливими потребами, гармонізувати відносини між членами сім’ї.

В останні роки все більше усвідомлюється психотерапевтична сутність малювання, музики, театру, як і будь-який інший художньої діяльності - мистецтва взагалі. Завдяки цьому стирається грань між психологічним обстеженням і психотерапевтіческім сеансом, а діагностичний інструментарій стає одночасно і засобом арттерапії. Широке застосування рісуночних i ігрових методів, таких як методика незакінчених речень, методика коментування картинок, методика завершення розповіді засноване на принципі проекції, тобто на винесенні зовні своїх переживань, бажань, прагнень і т.п.

Основним недоліком проективних методик вважається їх недостатня валідність, певний суб'єктивізм в інтерпретації результатів, відсутність статистичних методів обробки даних. Тому ці методи зазвичай використовуються в комплексі з іншими психодіагностичні методиками, порівнюються з результатами спостережень і бесід з членами родини. Результати діагностичної роботи дають фахівцеві інформацію про можливі причини дисфункції в родині у дитячо-батьківських відношеннях та мікроклімату родини, та є основним підгрунтям для побудови подальшої роботи з родиною.

\section{Література:}

1. Варга А. Я., Драбкина Т. С. Системная семейная психотерапия. Краткий лекционный курс. СПб.: Речь, 2001. - 144 с.

2. Консультування сім'ї: [методичні поради для консультування батьків]. - Частина 2/ за ред. В.Г.Постового. - К.: ДЦССМ, 2003. $-303 \mathrm{c}$.

3. Мастюкова Е. М., Московкина А. Г. Семейное воспитание детей с отклонениями в развитии: Учеб. пособие для студ. высш. учеб. заведений / Под ред. В.И.Селиверстова. - М.:Гуманит. изд. центр ВЛАДОС, 2003. -408 с.

4. Роджерс К. Р. Взгляд на психотерапию. Становление человека. М.: Издательская группа «Прогресс», «Универс», 1994. - 480 с.

5. Черников А. В. Системная семейная терапия: Интегративная модель диагностики. - М.: Независимая форма «Класс», 2005. 